\title{
Pelatihan Manajemen Usaha dan Investasi Pada Ikm Permen Susu "UD. Riskika” Desa Penyaring Kecamatan Moyo Utara Kabupaten Sumbawa
}

\author{
Santi Nururly*, Mukmin Suryatni, Sulaimiah, Emilia Septiani, Ilhamuddin \\ Fakultas Ekonomi dan Bisnis, Universitas Mataram, Indonesia
}

Kata Kunci: Permen Susu, Manajemen Usaha

\begin{abstract}
Abstrak: Desa Penyaring merupakan daerah peternakan Sapi Sumbawa yang diternakkan oleh masyarakat secara tradisional dengan melepaskan ternak di padang rumput (lar bahasa daerahnya). Sapi Sumbawa merupakan sapi multigna digunakan sebagai penghasil daging dan juga penghasil susu. Oleh masyarakat Penyaring biasanya susu dikonsumsi langsung, atau dibuat penganan yang berasal dari susu dan gula (disebut palopo), atau dijual ke industri kecil mikro (IKM) untuk diolah untuk membuat permen susu. IKM sebagian besar dikelola oleh masyarakat berpendidikan rendah dan hidup dalam kegiatan usaha kecil, Perkembangan jaman dan persaingan menuntut agar dapat bertahan di pasar dan dapat bersaing. Di Desa Penyaring Kecamatan Moyo Utara Kabupaten Sumbawa terdapat 11 IKM pembuat permen susu. Desa Penyaring kabupaten Moyo Utara berjarak $\pm 6 \mathrm{~km}$ dari kota Sumbawa Besar. Dalam kegiatan pengabdian ini dipilih IKM "UD. Riskika" yang merupakan IKM pertama dan sampai saat ini masih bertahan membuat permen susu. Permasalahan UD. Rizkika yaitu pengelola dan karyawan memiliki tingkat pendidikan rendah, dan pengetahuan tentang manajemen usaha masih terbatas. Tujuan kegiatan memberikan pelatihan tentang manajemen usaha yang meliputi kewirausahaan, pemasaran dan keuangan. Metode partisipatif digunakan dengan pendekatan ceramah dan diskusi. Pelatihan telah diadakan pada tanggal 13 Agustus 2019 dan kegiatan berhasil ditandai dengan respon peserta sangat antusias dan partisipasi tinggi. Kegiatan meliputi pelatihan kemasan produk permen susu yang baik dan higienis agar tidak cepat rusak, pelatihan aspek pemasaran; penggunaan internet untuk memperluas jaringan pemasaran, dan aspek keuangan diberikan pelatihan penentuan harga jual dan perhitungan pulang pokok (BEP).
\end{abstract}

\section{Korespondensi: snururly@unram.ac.id}

\section{PENDAHULUAN}

Desa penyaring merupakan daerah peternakan Sapi Sumbawa yang diternakkan oleh masyarakat secara tradisional dengan melepaskan ternak di padang rumput (lar bahasa daerahnya). Tahun 2015 populasi sapi sumbawa di Pulau Sumbawa 10.541 ekor; dan sebagian besar ada di Kabupaten Sumbawa yaitu 6.673 ekor. Dari populasi tersebut $60 \%$ ada di Desa Penyaring, Kecamatan Moyo Utara. Kabupaten Sumbawa sebagai wilayah pengembangan sapi sumbawa (d/h sapi Hissar) yang ditetapkan secara nasional pada tahun 1999 oleh pemerintah RI (Dilaga, 2014). Lebih lanjut dikatakan Sapi sumbawa merupakan sapi multiguna artinya dapat digunakan untuk dipekerjakan, penghasil daging dan susunya

Oleh masyarakat Penyaring biasanya susu dikonsumsi langsung, dibuat penganan yang berasal dari susu dan gula (disebut palopo), dan dijual ke Industri Kecil dan Mikro (IKM) pengolah susu untuk membuat permen susu. Permen Susu di buat secara sederhana dengan mencampur susu segar dan gula yang dipanaskan hingga menjadi karamel (Hadiwiyoto, 1983). Era Masyarakat Ekonomi Asean (MEA) mulai dicanangkan sejak 
tahun 2016. Pada era inilah pemerintah terus berupaya untuk memacu gairah ekonomi Indonesia. Salah satu caranya adalah dengan menggalakkan peran IKM. Alasannya, IKM sebagian besar dikelola oleh masyarakat berpendidikan rendah dan hidup dalam kegiatan usaha kecil, baik di sektor tradisional maupun modern. Strata masyarakat inilah yang dianggap paling sulit mengikuti irama MEA. Untuk itu pemerintah berkewajiban meningkatkan kemampuan mereka dalam berbagai bidang, guna menghadapi gempuran MEA tersebut. Harapannya adalah, mereka menjadi terberdayakan, sehingga mampu untuk meningkatkan daya saing produk lokal melalui kegiatan IKM.

Sejalan dengan roadmap Unram untuk pengembangan pulau-pulau kecil melalui peningkatan sumber daya manusia untuk mampu berdaya saing maka kegiatan pengabdian kepada masyarkat di lakukan Di Desa Penyaring Kecamatan Moyo Utara Kabupaten Sumbawa. Di Desa Penyaring terdapat 11 IKM pembuat permen susu. Desa Penyaring kabupaten Moyo utara berjarak $\pm 6 \mathrm{~km}$ dari kota Sumbawa Besar. Dalam kegiatan pengabdian ini dipilih IKM UD. Riskika yang merupakan IKM pertama dan sampai saat ini masih bertahan membuat permen susu. UD Riskika di ketuai oleh Ibu Siti Aisyah. Produk permen susu yang dihasilkan tergantung dari bahan baku yang tersedia rata-rata $7 \mathrm{~kg}$ per hari. Permen susu dikemas dengan kertas dan dijual dalam kemasan mika atau kotak kartun $1 / 4 \mathrm{~kg}$, $1 / 2 \mathrm{~kg}$ atau $1 \mathrm{~kg}$ dengan harga Rp 25.000,-, Rp. 50.000 dan Rp. 100.000,-.

UD. Riskika telah memiliki ijin usaha untuk produk permen susu berupa: PIRT, dan label halal dari MUI. Keinginan IKM untuk memperluas pasar maka perlu dilengkapi dengan label lengkap dengan informasi tentang komposisi, kandungan nutrisi, dan masa kadaluarsa.

Pemasaran permen susu dilakukan secara langsung atau berdasarkan pesanan, dan didistribusikan ke toko-toko terdekat dengan lokasi usaha, sekitar Sumbawa. Sehingga pemasaran permen susu masih terbatas. Oleh karena ingin memasarkan lebih luas maka produk permen susu yang dihasilkan mitra masih memiliki kelemahan. Oleh karena itu perlu dicarikan cara untuk meningkatkan pemasaran produk dengan memanfaatkan teknologi internet.

UD Riskika memiliki karyawan yang berasal dari keluarga terdekat dan ibu-ibu disekitar tempat tinggal. Untuk dapat meningkatkan kesejahteraan mereka maka salah satu cara dengan belajar investasi menabung emas. Mengapa emas, karena produk emas sudah dikenal sejak jaman dahulu sebagai salah satu alat nvestasi yang tidak rugi. Harga emas memiliki kecendrungan yang selalu naik. Untuk kegiatan investasi, tim pengabdian kepada masyarakat memilih menabung emas di Pegadaian

Tujuan dari kegiatan pengabdian pada masyarakat ini adalah untuk memberikan pelatihan kepada pemilik dan karyawan mitra IKM UD Riskika tentang kewirausahaan, manajemen usaha yang terdiri dari pemasaran dan keuangan, dan investasi. Diharapkan IKM UD.Rizkika dapat berkembang dan maju, dan dapat membeikan kebaikan bagi pemilik, dan karyawan untuk meningkatkan kehidupan di waktu mendatang.

\section{METODE KEGIATAN}

Kegiatan pengabdian pada masyarakat dilaksanakan dari bulan Juni sampai dengan Agustus 2019. Pelaksanaan kegiatan pengabdian dilaksanakan dengan mitra IKM UD. Riskika di Desa Penyaring Kecamatan Moyo Utara Kabupaten Sumbawa, terbagi dalam beberapa tahap; 
1. Persiapan

Dilaksanakan dengan survey lokasi, dan koordinasi dengan mitra. Survey lokasi dilakukan dengann wawancara untuk mengidentifikasi permasalahan yang dihadapi mitra, dan tim pengusul berkoordinasi dengan mitra untuk menentukan tempat dan waktu kegiatan.

2. Pelaksanaan

Kegiatan pelaksanaan digunakan dengan:

- Pendekatan ceramah dilakukan dalam kegiatan pelatihan Kewirausahaan. Pendekatan digunakan untuk memberikan pemahaman kepada khalayak tentang bagaimana membentuk jiwa kewirausahaan dan analisis usaha. Analisis usaha meliputi pelatihan tentang pentingnya kemasan menarik, dan untuk memperluas pangsa pasar dengan memberikan pelatihan tentang cara pemasaran melalui internet

- Untuk sesi peningkatan perilaku menabung untuk investasi, digunakan produk menabung Emas dari Pegadaian.

- Pemberi pelatihan kewirausahaan dan perilaku menabung dari Tim Pengabdian.

- Pendekatan Diskusi dilakukan untuk mendapatkan umpan balik tentang pengetahuan yang sudah diterima oleh khalayak sasaran.

3. Evaluasi

Mengevaluasi keberhasilan melalui antusiame partisipasi pemilik dan karyawan UD. Rizkika akan materi pelatihan.

\section{HASIL DAN PEMBAHASAN}

\section{Tahap Persiapan}

Pada tahap persiapan tim pengabdian melakukan survey awal di lokasi dengan berdialog dengan ibu Siti Aisyah sebagai pengelola permen susu UD Riskika mengenai peserta, tempat dan materi yang akan diberikan pada kegiatan pelatihan. Kegiatan pelatihan pengabdian pada masyarakat disi oleh Tim Pengabdian Pada Masyarakat.

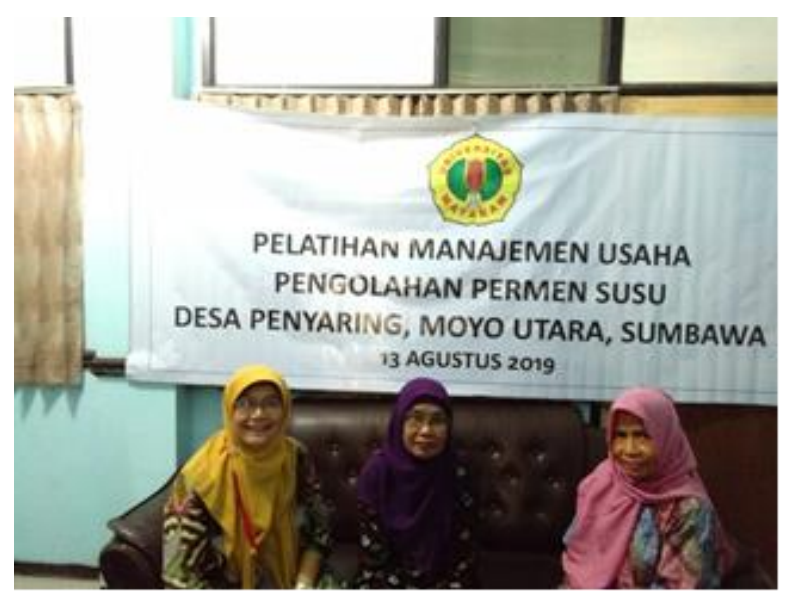

Gambar 1. Tim Pengabdian Masyarakat 


\section{Tahap Pelatihan}

Kegiatan pelatihan dilakukan oleh Tim pengabdian pada masyarakat dilaksanakan pada bulan Agustus 2019 bertempat di tempat usaha UD Riskika di Desa Penyaring Kecamatan Moyo Utara Kabupaten Sumbawa. Kegiaatan ditujukan kepada khalayak sasaran yaitu pemilik sekaligus pengelola usaha permen susu UD Riskika Ibu Siti Aisyah beserta karyawan UD Riskika. Pengusaha permen susu di Desa Penyaring rata-rata ibu-ibu, maka kegiatan pelatihan juga dihadiri oleh para pengusaha permen susu lainnya yang berada di Desa Penyaring. Awalnya kegiatan hanya ditujukan kepada UD Riskika, namun karena sesama pengusaha permen susu memiliki kedekatan dan lokasi usaha saling berdekatan sehingga tim pengabdian mengundang pula beberapa ibu pengelola usaha ng memproduksi permen susu di daerah tersebut.
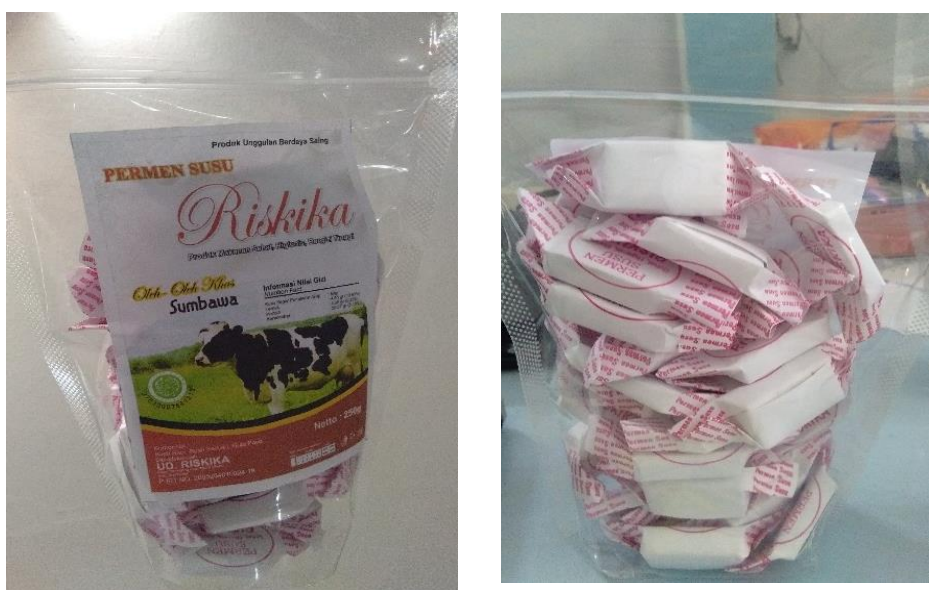

Gambar 1. Produk Permen Susu UD Riskika

Pelatihan yang diikuti oleh ibu-ibu pengelola usaha permen susu diberikan pelatihan yang memberikan makna mereka bukan hanya seorang pemilik, pedagang namun seorang wirausaha. Wirausaha (entrepreneur) adalah orang yang mempunyai sifat kewirausahaan, yakni kemampuan sesorang untuk melihat peluang-peluang bisnis, mengelola, dan memanfaatkannya dengan gagasan-gagasan yang senantiasa baru (kreatif dan inovatif), serta melembagakan dalam suatu perusahaan miliknya dengan risiko yang telah diperhitungkan untuk mencapai nilai tambah dan kesejahteraan (Supartha, 2005).

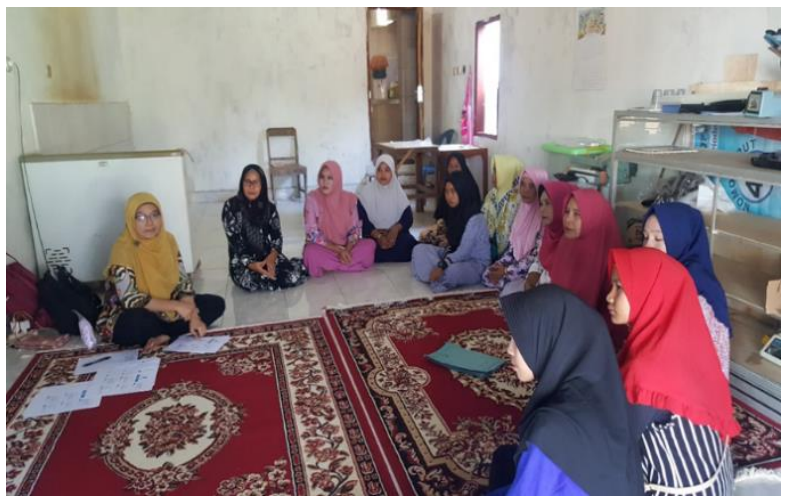

Gambar 2. Suasana Pelatihan di UD Riskika 
Dengan pelatihan ditanamkann jiwa kewirausahaan yang merupakan kemampuan seseorang dalam menghadapi lingkungannya, yang ditunjukkan oleh serangkaian sikap dan perilaku bagaimana memandang suatu kejadian, mengambil keputusan atas dasar pandangannya, bertindak mewujudkan keputusannya dan menerima konsekuensi dari tindakan tersebut sebagai bagian dari proses penghimpunan pengetahuan dan ketrampilan (Supartha dan Ramantha, 2010).

Antusiasme peserta pelatihan sangat tinggi ditandai dengan kehadiran peserta yang sesuai dengan target yang diharapkan. Diskusi diisi dengan berbagai pertanyaan sehubungan dengan isi materi yang diberikan. Adapun isi materi yang disampaikan pada pelatihan:

1. Kewirausahaan dan Motivasi berwirausaha dalam pengelolaan Usaha

2. Pemasaran yang efektif dengan kemasan yang menarik

3. Pemanfaatan Internet dalam pemasaran

4. Menghitung Titik Impas (Beak Event Point = BEP dan Harga Jual)

5. Investasi dengan menabung

Rerspon dari peserta pelatihan sangat besar ditandai dengan diskusi yang sangat aktif dan banyaknya pertanyaan yang dilontarkan.

\section{Evaluasi}

Tim pengabdian pada masyarakat memberikan pendampingan dan konsultasi atas produk, pemasaran dan pelatihan yang telah diberikan. Kegiatan ini diharapkan dapat berkelanjutan dan berkembang sehingga para peserta dapat:

1. Meningkatkan pengetahuan tentang pentingnya peranan sumber daya manusia dalam pengelolaan usaha.

2. Meningkatkan pengetahuan tentang kewirausahaan dan motivasi untuk mengembangkan usaha.

3. Meningkatkan pengetahuan akan pemasaran yang efektif,

4. Menumbuh kembangkan kreativitas dan inovasi produk melalui diversifikasi produk

5. Meningkatkan pengetahuan dan keterampilan dalam membuat pembukuan sederhana dan pengelolaan keuangan yang efektif

\section{KESIMPULAN DAN SARAN}

\section{Kesimpulan}

Kegiatan pengabdian pada masyarakat telah dilaksanakan di Desa Penyaring Moyo Utara berupa pelatihan dan pendampingan dari aspek pengelolaan usaha yang meliputi wirausaha, pemasaran, keuangan dan investasi. Dengan kegiatan pengabdian ini para pengusaha dan pengelola usaha sudah mendapatkan pengetahuan tentang pentingnya kewirausahaan, pemasaran dengan memanfaatkan internet, serta perhitungan break event point. Pendampingan telah dilakukan untuk membantu penerapan pada kegiatan usaha.

\section{Saran}

Pelatihan yang diberikan hendaknya terus diimplementasikan dan dikembangkan untuk meningkatkan pendapatan dari pengusaha permen susu. 


\section{Ucapan Terima Kasih}

Kegiatan pengabdian pada masyarakat ini dapat berjalan dengan lancar dengan bersumber dari Dana DIPA BLU Universitas Mataram Tahun Anggaran 2019. Terima kasih kepada Fakultas Ekonomi dan Bisnis Universitas Mataram, Lembaga Penelitian dan Pengabdian Pada Masyarakat Universitas Mataram, serta IKM UD Rizkika sehingga kegiatan ini dapat berjalan dengan lancar.

\section{DAFTAR PUSTAKA}

Dilaga, SH. 2014. Sapi Sumbawa: Sumber Daya Genetik Ternak Indonesia. Penerbit Pustaka Reka Cipta. Bandung

Hadiwiyoto.S. 1983.Susu dan Hasil Olahannya. Penerbit Liberty. Yogyakarta

Suparta, N dan I.W. Ramantha, 2010. Manajemen Bisnis Kecil dan Kewirausahaan. Cetakan Pertama. Pustaka Nayottama. Denpasar 